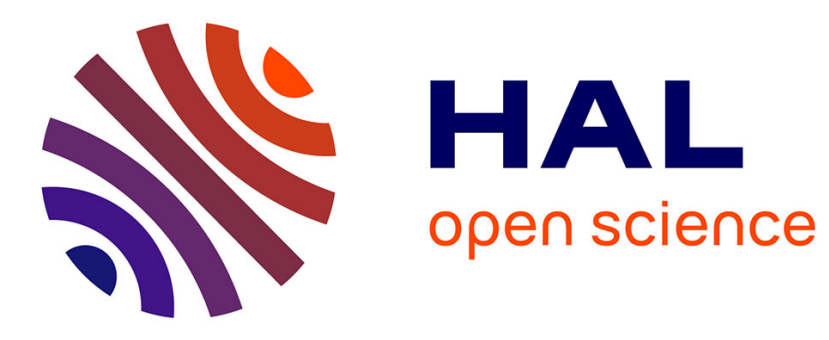

\title{
Ultradeep sequencing reveals HIV-1 diversity and resistance compartmentalization
}

Eleni Giatsou, Basma Abdi, Isabelle Plu, Nathalie Désiré, Romain Palich, Vincent Calvez, Danielle Seilhean, Anne-Geneviève Marcelin, Aude Jary

\section{- To cite this version:}

Eleni Giatsou, Basma Abdi, Isabelle Plu, Nathalie Désiré, Romain Palich, et al.. Ultradeep sequencing reveals HIV-1 diversity and resistance compartmentalization. AIDS. Official journal of the international AIDS Society, 2020, 34 (11), pp.1609-1614. 10.1097/QAD.0000000000002616 . hal-02996294

\section{HAL Id: hal-02996294 \\ https://hal.sorbonne-universite.fr/hal-02996294}

Submitted on 9 Nov 2020

HAL is a multi-disciplinary open access archive for the deposit and dissemination of scientific research documents, whether they are published or not. The documents may come from teaching and research institutions in France or abroad, or from public or private research centers.
L'archive ouverte pluridisciplinaire HAL, est destinée au dépôt et à la diffusion de documents scientifiques de niveau recherche, publiés ou non, émanant des établissements d'enseignement et de recherche français ou étrangers, des laboratoires publics ou privés. 
1 Title: Ultradeep sequencing reveals HIV-1 diversity and resistance compartmentalization

2 during HIV-encephalopathy

3

4 Short title: HIV-compartmentalization in the CNS

5 (8 21 22 23

Eleni GIATSOU ${ }^{1}$, Basma ABDI ${ }^{1}$, Isabelle PLU $^{2}$, Nathalie DESIRE ${ }^{1}$, Romain PALICH ${ }^{3}$, Vincent CALVEZ ${ }^{1}$, Danielle SEILHEAN ${ }^{2}$, Anne-Geneviève MARCELIN ${ }^{1}$, Aude JARY ${ }^{1}$

${ }^{1}$ Sorbonne Université, INSERM, Institut Pierre Louis d'Epidémiologie et de Santé Publique (iPLESP), AP-HP, Hôpital Pitié Salpêtrière, Laboratoire de Virologie, F-75013 Paris, France

${ }^{2}$ Sorbonne Université, APHP, Hôpital Pitié Salpêtrière, Département de Neuropathologie Raymond Escourolle, F-75013, Paris, France

${ }^{3}$ Sorbonne Université, INSERM, Institut Pierre Louis d'Epidémiologie et de Santé Publique (iPLESP), AP-HP, Hôpital Pitié Salpêtrière, Service de Maladies Infectieuses et Tropicales, F-75013 Paris, France

Corresponding author: Dr Aude Jary, Virology Laboratory, CERVI, Pitié-Salpêtrière Hospital, 83 Bd de l'hôpital, 75013, Paris, France. Email Address: aude.jary@aphp.fr

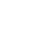
4

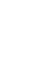




\section{ABSTRACT}

Objectives: To examine viral diversity and resistance mutations in different brain areas in cases of HIV-encephalopathy.

Design: Twelve post-mortem brain areas from 3 cases of possible or certain HIVencephalopathy were analyzed.

Methods: After amplification of the reverse transcriptase and the V3 loop region of the gp120 protein, ultradeep sequencing was performed with Illumina ${ }^{\circledR}$ technology. Phylogenetic analysis was performed with Fastree v2.1 using the generalized time-reversible (GTR) model. Identification of resistant viral variants was performed on Geneious software, according to HIV-1 genotypic drug resistance interpretation's algorithms, 2018 administered by the French Agency for Research on AIDS and Viral Hepatitis.

Results: Phylogenetic analysis revealed significant inter-regional and intra-regional diversity reflecting persistent HIV-1 viral replication in the different brain areas. Although some cerebral regions shared HIV-variants, most of them harbored a specific HIV-subpopulation reflecting HIV compartmentalization in the central nervous system. Furthermore, proportion and distribution of resistance mutations to Nucleoside and Non-Nucleoside Reverse Transcriptase Inhibitors differed among different brain areas of the same case suggesting that penetration of antiretroviral treatment may differ from one compartment to another.

Conclusions: This study, performed with a powerful sequencing technique, confirmed HIV compartmentalization in the central nervous system already shown by classical sequencing, suggesting that there are several reservoirs within the brain.

Keywords: HIV-encephalitis; compartmentalization; viral diversity; resistance mutation; ultradeep sequencing 


\section{INTRODUCTION}

The Human Immunodeficiency Virus (HIV) enters the brain causing HIVencephalopathy. The multinucleated giant cell (MGC), formed by cell-to-cell fusion of infected macrophages with microglia is the hallmark of this disease [1].

HIV-persistence in the CNS is principally due to weak penetration of antiretroviral drugs through the blood-brain-barrier [2,3]. Sanger-sequencing has shown independent evolution of drug resistance mutations to Nucleoside and Non-Nucleoside Reverse Transcriptase Inhibitors (NRTIs/NNRTIs) and protease inhibitors (PI) in different brain areas suggesting that differential drug penetration may occur among them [4]. Ultra-deep sequencing (UDS) detects minority variants that represent up to $1 \%$ of the HIV-1 population and that were incriminated for systemic therapeutic failure in treatment naïve patients [5-8]. Moreover, phylogenetic studies based on Sanger-sequencing determined brain-specific variants [9-11]. Analysis of the envelope gene in either Sanger or Single Molecule Real Time (SMRT) sequencing showed viral strains within the CNS evolving independently in different brain areas in patients who died from HIV-encephalopathy [12]. More specifically, uniquely divergent viral strains were identified in frontal, occipital, parietal, temporal lobes and basal ganglia [12-14].

In this study, we used UDS to describe HIV-diversity in the CNS by sequencing the reverse transcriptase (RT) gene and the hypervariable V3 loop region of the HIV-1 gp120 envelope protein, to detect minority resistant variants and to identify HIV-1 tropism in specimens derived from different brain areas in three HIV+ cases of HIV encephalopathy.

\section{METHODS}


Twelve post-mortem brain tissues from 3 HIV-positive cases of probable or certain HIVencephalopathy were provided by the Raymond Escourolle Neuropathology laboratory of the Pitié-Salpêtrière Hospital. The twelve tissues represented temporal and frontal lobe, caudate nucleus, thalamus, cerebellum, medulla oblongata, substantia nigra and spinal cord. The first case (C1) concerned a 48-year-old woman, HIV-positive for ten years, treated by multiple antiretroviral therapy. The second case (C2) concerned a 38-year-old man, HIV-positive for nine years, never treated. Concerning the third case (C3), a 29-year-old woman, she received treatment but no data was available on duration and date of HIV-diagnosis. Information on clinical course, specific HIV treatment history and biological parameters was limited, as the majority of medical records have been destroyed (Supplementary Table 1).

After DNA/RNA extraction, HIV proviral-DNA was quantified with Generic HIV DNA Cell ${ }^{\circledR}$ kit (Biocentric $®)$. RT (RT1 and RT2) and V3 loop regions were amplified by nested PCR (Supplementary Table 2) and sequencing was performed by Illumina ${ }^{\circledR}$ MiSeq (paired-end, 2x300bp).

Viral diversity. Geneious Prime software (Biomatters Ltd, Auckland, NZ) was used to keep reads with a Q-score > 30 and longer than $200 \mathrm{bp}$ and to pair forward and reverse reads to form complete RT1, RT2 and V3 regions. Sequences in 100\% agreement were grouped to form consensus sequences (CS). Second round was performed with sequences in 99\% agreement then $98 \%$ and finally $97 \%$ as previously described [15]. Then, multiple alignments of all CS and HXB2 reference genome was performed using Mafft Software v7 [16]. Phylogenetic analysis was performed using approximately-maximum-likehood method with FastTree v2.1 using generalized time-reversible (GTR) model on both all CS (HIV_RT1_CS 
and HIV_V3_CS) and CS after cleaning viral CS found less than 100 times in each brain area (HIV_RT1_CS100 and HIV_V3_CS100).

To compare, Sanger sequencing was also performed according to the ANRS (French Agency for HIV research and Hepatitis) technique (http://www.hivfrenchresistance.org/). Multiple alignment of nucleotide sequences was performed with Mafft [16] and phylogenetic analysis with PhyML using GTR model and 1000 bootstrap resampling.

Finally, HIV-1 tropism was determined with geno2pheno (https://coreceptor.geno2pheno.org/) according to the recommendations of the European Consensus Group on clinical management of HIV-1 tropism testing (10\% FPR).

Single-nucleotide polymorphisms (SNPs). Cleaned reads of RT1/RT2 issued from UDS (see previous paragraph) were mapped against $\mathrm{HXB} 2$ that carried annotations for the RT to identify SNPs (synonymous and non-synonymous SNPs, the coverage and the number of reads carrying polymorphism). The minimum variant frequency was set at $1 \%$. Finally, HIV-1 $\begin{array}{llll}\text { genotypic drug } & \text { resistance interpretation's } & \text { algorithms, } & 2018\end{array}$ (http://www.hivfrenchresistance.org/table.html) administered by the French Agency for Research on AIDS and Viral Hepatitis were used to identify resistance mutations.

\section{RESULTS}

HIV proviral-DNA load was only detected in C2 temporal lobe and medulla oblongata specimen as well as in all C3 specimens mentioned in increasing order: cerebellum (23 copies/ $10^{6}$ cells), medulla oblongata (31 copies/ $10^{6}$ cells), temporal lobe $\left(91\right.$ copies/ $10^{6}$ cells), substantia nigra (92 copies/ $10^{6}$ cells), caudate nucleus (130 copies/ $10^{6}$ cells), and frontal lobe (544 copies/ $10^{6}$ cells) (Table 1). 
Phylogenetic trees were generated using both HIV_RT1_CS (Supplementary Figure 1) and HIV_RT1_CS100 (Figure 1) and viral diversity is depicted in Table 1.

Viral diversity of RT1 for C1 was very high varying from 1086 to 3453 different viral CS in each brain area. Viral variants isolated from temporal lobe, caudate nucleus and spinal cord clustered independently (Figure 1A). However, a small part of viral strains derived from caudate nucleus and spinal cord was intermingled with 15 common CS between the two areas ( $0.6 \%$ and $0.4 \%$ of their CS, respectively). Viral diversity of $\mathrm{C} 2$ was also very high in temporal lobe region and medulla oblongata (3259 and 3189 respectively) with a clear separation of viral population between the two compartments and only 3 common CS (0.09\%). Considering HIV_RT1_CS100, no viral population was shared between C2's compartments (Figure 1C). Finally, for C3, viral variants isolated from substantia nigra clustered independently (both HIV_RT1_CS and HIV_RT_CS100) from caudate nucleus, cerebellum and frontal lobe variants. However, among the last 3 brain areas, 527 viral CS were shared (20\% of frontal CS, $21.5 \%$ of caudate nucleus CS and $15 \%$ of cerebellum CS) (Figure 1D).

By Sanger sequencing similar results were found, specifically sequences from $\mathrm{C} 1$ and $\mathrm{C} 2$ clustered independently. However, in C3, sequences from cerebellum, caudate nucleus and frontal lobe clustered together and these results may explain the more important proportion of common CS obtained by UDS between these 3 brain areas (Supplementary Figure 2).

The analysis of the V3 loop region for $\mathrm{C} 1$ also showed about thousand different viral CS per brain area with a limited number of them common between temporal lobe and spinal cord (Figure 1B). HIV-1 tropism was analyzed with HIV_V3_CS100: 94\% (72/77) of spinal cord CS100 and 96\% (126/131) of temporal lobe CS100 were predicted to use the CCR5 co- 
receptor. The remaining CS100 of the two brain areas were undetermined and none was predicted to use CXCR4 co-receptor (Supplementary Table 3).

\section{amplified for RT1. They were carried by either majority or minority variants depending on} brain area and they reflected the viral diversity previously found (Supplementary Table 4). SNPs conferring resistance to ZDV, ABC, TDF/ FTC (NRTIs) and ETR (NNRTIs) if associated to other mutations of the RT gene were found: specifically, M41L conferring resistance to NRTIs and V90L and V106I to the NNRTI (Table 1). In C1, the majority of caudate nucleus's and spinal cord's variants harbored M41L (98, 4\% each) and V90L (96.7\% and $97.6 \%$ respectively) not found in temporal lobe. In C2, no resistance mutations were identified in neither temporal lobe nor medulla oblongata. In C3, minority variants in caudate nucleus and substantia nigra carried V90I (16.2\% and $1.6 \%$ respectively). However, V106I was carried only by $1 \%$ of variants in caudate nucleus and M41L only by $2.3 \%$ of variants in substantia nigra. Finally, no resistance mutations were identified in neither frontal lobe nor cerebellum.

\section{DISCUSSION}

The CNS is an important viral reservoir of HIV and can be particularly difficult to target as a consequence of limited drug penetration [17,18]. This study is the first to use Illumina ${ }^{\circledR}$ technology to describe viral diversity and to analyze resistance mutations to NRTIs/NNRTIs in diverse areas of the CNS in three cases diagnosed with probable or certain HIV-encephalopathy. These cases concern a woman and a man with a long HIV disease 
course, either treated or not respectively, as well as a treated woman for whom disease duration is unknown.

175 Firstly, we found that HIV proviral-DNA load varied both among different cases and among different brain areas of a single case as previously reported for HIV-RNA load in different brain regions of HIV+ cases [19]. However, the highest rates were not necessarily found in the same areas among studies and such discordance may be expected because DNA load reflects the size of the viral reservoir and not cell-free replicating virus [20]. In C1, although HIV proviral-DNA load was undetectable, sequencing and viral diversity analysis were effective in 3 of the 4 samples. This discrepancy may be explained by a higher sensibility of nested PCR compared to real-time PCR or the use of different primers between the two techniques.

Although RT1 sequencing for the C1's and C2's cerebellum and C2's thalamus specimens, RT2 for all cases and V3 for C2 and C3 failed, our results of viral diversity and tropism were consistent with those previously obtained by SMRT on an HIV+/cART+ case diagnosed with HIV encephalopathy. Indeed, the authors showed by sequencing full-length envelope gene that frontal lobe sequences clustered independently of occipital and parietal lobes and all of them were predicted to use CCR5 co-receptor while most non-brain sequences were predicted to use CXCR4 co-receptor. In our study, the majority of brain areas harbored a distinct HIVsubpopulation and those with effective V3 sequencing showed that strains used CCR5 coreceptor. While some variants isolated from caudate nucleus were intermixed to various degrees with sequences from spinal cord, frontal lobe or cerebellum region, brainstem (substantia nigra and medulla oblongata) harbored a specific subpopulation in $\mathrm{C} 2$ and $\mathrm{C} 3$. Overall, our results confirm previous evidence by Sanger-sequencing that several HIVreservoirs exist within the CNS $[13,14]$ and prove a high intra-regional and inter-regional viral diversity just like a study based on SMRT [12], reflecting persistent viral replication in 
the CNS. Compartmentalization is evident in all of our three cases regardless of treatment status. However, in $\mathrm{C} 2$, who received no treatment, there is a clear separation of viral population between the two compartments examined, while in $\mathrm{C} 1$ and $\mathrm{C} 3$ who received treatment, we note some common viral strains between two regions.

HIV-1 resistance mutations to antiretroviral drugs were reported to be regionally distributed in diverse areas of the brain by classical sequencing (15). Our study, detecting minority variants up to $1 \%$ by UDS, found similar results with different distribution of resistance mutations among brain areas of the same case. These results suggest that selection pressure may vary across brain compartments and that antiretroviral treatment does not penetrate equally all of them. Finally, resistance mutations were expected in $\mathrm{C} 1$ and $\mathrm{C} 3$ who received treatment unlike $\mathrm{C} 2$ for whom no mutation was found.

In conclusion, this study shows significant inter-regional and intra-regional viral diversity and confirms HIV-compartmentalization in different brain areas already shown by studies based on classical sequencing suggesting that there are several reservoirs within the CNS. 
Funding. This work was funded by the Agence Nationale de Recherche sur le SIDA et les 229 group.

230

Authors contributions. Conception and design of the study: IP, VC, DS, AGM; acquisition and analysis of the data: EG, BA, ND, RP, AJ; drafting of significant portion of the manuscript or figures: EG, AJ. All the authors read, corrected and approved the final manuscript.

Conflicts of interest. No conflicts of interest to disclose.

Meeting presentation. This work was presented as an e-poster at the Conference on 


\section{REFERENCES}

2531 González-Scarano F, Martín-García J. The neuropathogenesis of AIDS. Nat Rev Immunol 2005; 5:69-81.

2 Bhaskaran K, Mussini C, Antinori A, Walker AS, Dorrucci M, Sabin C, et al. Changes in the incidence and predictors of human immunodeficiency virus-associated dementia in the era of highly active antiretroviral therapy. Ann Neurol 2008; 63:213-221.

3 Robertson KR, Smurzynski M, Parsons TD, Wu K, Bosch RJ, Wu J, et al. The prevalence and incidence of neurocognitive impairment in the HAART era. AIDS 2007; 21:1915-1921.

4 Smit TK, Brew BJ, Tourtellotte W, Morgello S, Gelman BB, Saksena NK. Independent evolution of human

5 Cozzi-Lepri A, Noguera-Julian M, Di Giallonardo F, Schuurman R, Däumer M, Aitken S, et al. Low-frequency drug-resistant HIV-1 and risk of virological failure to first-line NNRTI-based ART: a multicohort European case-control study using centralized ultrasensitive 454 pyrosequencing. J Antimicrob Chemother 2015; 70:930-940.

6 Li JZ, Paredes R, Ribaudo HJ, Svarovskaia ES, Metzner KJ, Kozal MJ, et al. Low-frequency HIV-1 drug resistance mutations and risk of NNRTI-based antiretroviral treatment failure: a systematic review and pooled analysis. JAMA 2011; 305:1327-1335.

7 Stella-Ascariz N, Arribas JR, Paredes R, Li JZ. The Role of HIV-1 Drug-Resistant Minority Variants in Treatment Failure. J Infect Dis 2017; 216:S847-S850.

8 Hodkinson BP, Grice EA. Next-Generation Sequencing: A Review of Technologies and Tools for Wound Microbiome Research. Adv Wound Care (New Rochelle) 2015; 4:50-58.

9 Epstein LG, Kuiken C, Blumberg BM, Hartman S, Sharer LR, Clement M, et al. HIV-1 V3 domain variation in brain and spleen of children with AIDS: tissue-specific evolution within host-determined quasispecies. Virology 1991; 180:583-590.

10 Caragounis E-C, Gisslén M, Lindh M, Nordborg C, Westergren S, Hagberg L, et al. Comparison of HIV-1 pol and env sequences of blood, CSF, brain and spleen isolates collected ante-mortem and post-mortem. Acta Neurol Scand 2008; 117:108-116.

11 Gonzalez-Perez MP, O'Connell O, Lin R, Sullivan WM, Bell J, Simmonds P, et al. Independent evolution of macrophage-tropism and increased charge between HIV-1 R5 envelopes present in brain and immune tissue. Retrovirology 2012; 9:20.

12 Brese RL, Gonzalez-Perez MP, Koch M, O’Connell O, Luzuriaga K, Somasundaran M, et al. Ultradeep singlemolecule real-time sequencing of HIV envelope reveals complete compartmentalization of highly macrophage-tropic R5 proviral variants in brain and CXCR4-using variants in immune and peripheral tissues. J Neurovirol 2018; 24:439-453.

13 Shapshak P, Segal DM, Crandall KA, Fujimura RK, Zhang BT, Xin KQ, et al. Independent evolution of HIV type 1 in different brain regions. AIDS Res Hum Retroviruses 1999; 15:811-820.

14 Chang J, Jozwiak R, Wang B, Ng T, Ge YC, Bolton W, et al. Unique HIV type 1 V3 region sequences derived from six different regions of brain: region-specific evolution within host-determined quasispecies. AIDS Res Hum Retroviruses 1998; 14:25-30.

15 Nguyen T, Delaugerre C, Valantin M-A, Amiel C, Netzer E, L'yavanc T, et al. Shared HCV Transmission Networks among HIV-1 Positive and Negative Men Having Sex with Men by Ultra-Deep Sequencing. J Acquir Immune Defic Syndr Published Online First: 21 May 2019. doi:10.1097/QAl.0000000000002099 
16 Katoh K, Standley DM. MAFFT multiple sequence alignment software version 7: improvements in performance and usability. Mol Biol Evol 2013; 30:772-780.

17 Gray LR, Roche M, Flynn JK, Wesselingh SL, Gorry PR, Churchill MJ. Is the central nervous system a reservoir of HIV-1? Curr Opin HIV AIDS 2014; 9:552-558.

18 Spudich S, Robertson KR, Bosch RJ, Gandhi RT, Cyktor JC, Mar H, et al. Persistent HIV-infected cells in cerebrospinal fluid are associated with poorer neurocognitive performance. 2019. doi:10.1172/JCl127413

19 Kumar AM, Borodowsky I, Fernandez B, Gonzalez L, Kumar M. Human immunodeficiency virus type 1 RNA Levels in different regions of human brain: quantification using real-time reverse transcriptasepolymerase chain reaction. J Neurovirol 2007; 13:210-224.

20 Chun T-W, Murray D, Justement JS, Hallahan CW, Moir S, Kovacs C, et al. Relationship between residual plasma viremia and the size of HIV proviral DNA reservoirs in infected individuals receiving effective antiretroviral therapy. J Infect Dis 2011; 204:135-138.

306

307

308

309

310 


\begin{tabular}{|c|c|c|c|c|c|}
\hline & \multicolumn{2}{|c|}{ CASE 1} & CASE 2 & \multicolumn{2}{|c|}{ CASE 3} \\
\hline & \multicolumn{3}{|c|}{ Temporal lobe } & \multicolumn{2}{|c|}{ Frontal lobe } \\
\hline HIV proviral DNA (copies $/ 10^{6}$ cells) & \multicolumn{2}{|c|}{$<40$} & 91 & \multicolumn{2}{|c|}{544} \\
\hline $\begin{array}{r}\text { HIV_RT1_CS } \\
\text { No } \\
\text { No shared (\%) }\end{array}$ & \multicolumn{2}{|c|}{$\begin{array}{c}1086 \\
1(0.09) \text { with CN }\end{array}$} & $\begin{array}{c}3259 \\
3(0.09) \text { with MO }\end{array}$ & \multicolumn{2}{|c|}{$\begin{array}{c}2624 \\
527 \text { (20.1) with CN and Cer } \\
55(2.1) \text { only with CN } \\
83 \text { (3.2) only with Cer }\end{array}$} \\
\hline $\begin{array}{l}\text { HIV_RT1_CS100 } \\
\text { No } \\
\text { No shared (\%) }\end{array}$ & \multicolumn{2}{|c|}{$\begin{array}{c}2 \\
0(0)\end{array}$} & $\begin{array}{l}146 \\
0(0)\end{array}$ & \multicolumn{2}{|c|}{$\begin{array}{c}30 \\
7 \text { (23.3) with CN and Cer } \\
3 \text { (10) only with Cer }\end{array}$} \\
\hline $\begin{array}{l}\text { Resistance mutation } \\
\text { Nucleotide substitution (position) } \\
\text { coverage } \\
\% \text { reads carrying mutation } \\
\text { No of reads carrying mutation }\end{array}$ & & & $\begin{array}{l}0 \\
- \\
- \\
- \\
-\end{array}$ & & \\
\hline & \multicolumn{2}{|c|}{ Caudate nucleus } & Thalamus & \multicolumn{2}{|c|}{ Caudate nucleus } \\
\hline HIV proviral DNA (copies $/ 10^{6}$ cells) & \multicolumn{2}{|c|}{$<40$} & $<40$ & \multicolumn{2}{|c|}{130} \\
\hline $\begin{aligned} \text { HIV_RT1_CS } & \text { No } \\
& \text { No shared }(\%)\end{aligned}$ & \multicolumn{2}{|c|}{$\begin{array}{c}2590 \\
15(0.6) \text { with SC } \\
1(0.04) \text { with TL }\end{array}$} & Not amplified & \multicolumn{2}{|c|}{$\begin{array}{c}2451 \\
527(21.5) \text { with FL and SN } \\
234(9.5) \text { only with Cer } \\
55(2.2) \text { only with FL }\end{array}$} \\
\hline $\begin{array}{c}\text { HIV_RT1_CS100 } \\
\text { No } \\
\text { No shared }(\%)\end{array}$ & \multicolumn{2}{|c|}{$\begin{array}{c}141 \\
2(1.4) \text { with SC }\end{array}$} & Not amplified & \multicolumn{2}{|c|}{$\begin{array}{c}60 \\
7 \text { (11.7) with FL and Cer } \\
9(15) \text { only with Cer }\end{array}$} \\
\hline $\begin{array}{l}\text { Resistance mutation } \\
\text { Nucleotide substitution (position) } \\
\text { coverage } \\
\% \text { reads carrying mutation } \\
\text { No of reads carrying mutation }\end{array}$ & $\begin{array}{c}\text { M41 L } \\
\text { A-C (586) } \\
289139 \\
98,4 \\
284513 \\
\end{array}$ & $\begin{array}{c}\text { V90 I } \\
\text { G-A (733) } \\
552684 \\
96,7 \\
534445\end{array}$ & Not amplified & $\begin{array}{c}\text { V90 I } \\
\text { G-A (733) } \\
328900 \\
16,2 \\
53282\end{array}$ & $\begin{array}{c}\text { V106 I } \\
\text { G-A (781) } \\
328913 \\
1 \\
3289\end{array}$ \\
\hline & \multicolumn{5}{|c|}{ Cerebellum } \\
\hline HIV proviral DNA (copies $/ 10^{6}$ cells) & \multicolumn{2}{|c|}{$<40$} & $<40$ & \multicolumn{2}{|c|}{23} \\
\hline $\begin{array}{r}\text { HIV_RT1_CS } \\
\text { No shared (\%) }\end{array}$ & \multicolumn{2}{|c|}{ Not amplified } & Not amplified & \multicolumn{2}{|c|}{$\begin{array}{c}3526 \\
527 \text { (14.9) with FL and CN } \\
234 \text { (6.6) only with CN } \\
83 \text { (2.4) only with FL }\end{array}$} \\
\hline $\begin{array}{c}\text { HIV_RT1_CS100 } \\
\text { No } \\
\text { No shared }(\%)\end{array}$ & \multicolumn{2}{|c|}{ Not amplified } & Not amplified & \multicolumn{2}{|c|}{$\begin{array}{c}73 \\
7 \text { (9.6) with FL and CN } \\
9(12.3) \text { only with CN } \\
\text { 3(4.1) only with FL }\end{array}$} \\
\hline $\begin{array}{l}\text { Resistance mutation } \\
\text { Nucleotide substitution (position) } \\
\text { coverage } \\
\% \text { reads carrying mutation } \\
\text { No of reads carrying mutation }\end{array}$ & \multicolumn{2}{|c|}{ Not amplified } & Not amplified & & \\
\hline & Spina & cord & Medulla oblongata & Subst & nigra \\
\hline HIV proviral DNA (copies $/ 10^{6}$ cells) & & & 31 & & \\
\hline $\begin{array}{r}\text { HIV_RT1_CS } \\
\text { No shared (\%) } \\
\text { No she }\end{array}$ & $\begin{array}{r}34 \\
15(0.4) \\
\end{array}$ & ith $\mathrm{CN}$ & $\begin{array}{c}3189 \\
3(0.09) \text { with TL } \\
\end{array}$ & & \\
\hline $\begin{array}{c}\text { HIV_RT1_CS100 } \\
\text { No } \\
\text { No shared }(\%)\end{array}$ & $2(1.3)^{1}$ & th $\mathrm{CN}$ & $\begin{array}{c}72 \\
0(0)\end{array}$ & & \\
\hline Resistance mutation & M41 L & V90 I & 0 & M41 L & V90 I \\
\hline $\begin{array}{c}\text { Nucleotide substitution (position) } \\
\text { coverage } \\
\% \text { reads carrying mutation } \\
\text { No of reads carrying mutation }\end{array}$ & $\begin{array}{c}\text { A-C (586) } \\
384658 \\
98,4 \\
378503\end{array}$ & $\begin{array}{c}\text { G-A (733) } \\
618797 \\
97,6 \\
603946\end{array}$ & $\begin{array}{l}- \\
- \\
- \\
-\end{array}$ & $\begin{array}{c}\text { A-C (586) } \\
62637 \\
2,3 \\
1441\end{array}$ & $\begin{array}{c}\text { G-A (733) } \\
100327 \\
1,6 \\
1605\end{array}$ \\
\hline
\end{tabular}


328 Cer: cerebellum; CN: caudate nucleus; CS: consensus sequences; DNA: desoxyribonucleic acid; FL: frontal 329 lobe; HIV: human immunodeficiency virus; MO: medulla oblongata; No: number; SC: spinal cord; SN: 330 substantia nigra; TL: temporal lobe; -: not applicable; No: number

331 HIV_RT1_CS: all cleaned consensus sequences of RT1 fragment; HIV_RT1_CSIO0: all cleaned consensus 332 sequences of RT1 fragment after filtering out consensus sequences found less than 100 times

333 In case 1, the majority of caudate nucleus's and spinal cord's variants shared the same resistance mutations 334 M41L and V90I. M41L: the substitution of methionine for leucine in position 41 of RT1 confers resistance to

335 ZDV, ABC and TDF/FTC (NRTIs) on condition that this substitution is associated to two others specific mutations within the RT gene. V90I: The substitution of valine for isoleucine in position 90 of RT1 confers resistance to ETR (NNRTI) only if two others mutations are presents within the RT gene. No resistance mutation was identified in any of brain areas studied in case 2 (temporal lobe and medulla oblongata). Case 3 presented resistance mutations only in caudate nucleus and substantia nigra. V106I: The substitution of valine for isoleucine in position 106 confers resistance to ETR only if associated to two others specific mutations of the RT gene. 

Fastree (2.1) of RT1 consensus viral sequences issued from the different brain areas. Phylogenetic trees were inferred with viral consensus after filtered out those found less than C2, D. RT1 of C3.

Branches are colored according to the tissue origin as follow: red: caudate nucleus; blue (C1 and C2: temporal lobe, C3: frontal lobe); green: spinal cord; yellow: brainstem (C2: medulla oblongata and C3: substantia nigra); pink: cerebellum

362

363

364

365

366

367

368

369

370

371

372

373

374

375

376 
379 Supplementary Figure 1: Approximately maximum-likelihood phylogenetic trees 380 constructed with Fastree (2.1) of RT1 consensus viral sequences issued from the 381 different brain areas. Phylogenetic trees were inferred with all viral consensus found (HIV_RT1_CS or HIV_V3_CS). A. RT1 of C1, B. V3 of C1, C. RT1 of C2, D. RT1 of C3. Branches are colored according to the tissue origin as follow: red: caudate nucleus; blue (C1 and C2: temporal lobe, C3: frontal lobe); green: spinal cord; yellow: brainstem (C2: medulla oblongata and C3: substantia nigra); pink: cerebellum

386

387

388

389

390

391

392

393

394

395

396

397

398

399

400

401

402

403

404 
405 Supplementary Figure 2: Maximum-likelihood phylogenetic tree constructed with 406 PhyML of RT1 nucleotide sequences issued from the different brain areas. Phylogenetic 407 tree were inferred with nucleotide sequences generated by Sanger sequencing and rooted with 408 HXB2 reference sequence. Branches are colored according to the tissue origin as follow: red: 409 caudate nucleus; blue (C1 and C2: temporal lobe, C3: frontal lobe); green: spinal cord; 410 yellow: brainstem (C2: medulla oblongata and C3: substantia nigra); pink: cerebellum

411 Nodes presenting a branch support > 70\% (bootstrap analysis with 1000 replicates) are $412 \quad$ indicated by an asterisk. 
Supplementary Figure 1: Approximately maximum-likelihood phylogenetic trees constructed with Fastree (2.1) of RT1 consensus viral sequences issued from the different brain areas. Phylogenetic trees were inferred with all viral consensus found (HIV_RT1_CS or HIV_V3_CS). A. RT1 of C1, B. V3 of C1, C. RT1 of C2, D. RT1 of C3. Branches are colored according to the tissue origin as follow: red: caudate nucleus; blue (C1 and C2: temporal lobe, C3: frontal lobe); green: spinal cord; yellow: brainstem (C2: medulla oblongata and C3: substantia nigra); pink: cerebellum

A

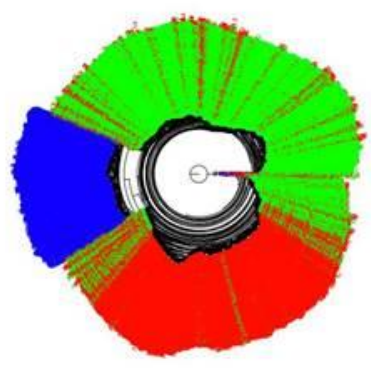

$\overline{0.02}$

C

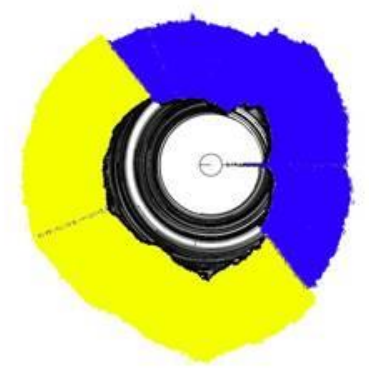

0.04
B

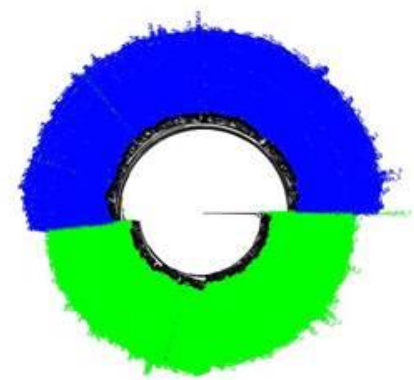

0.02

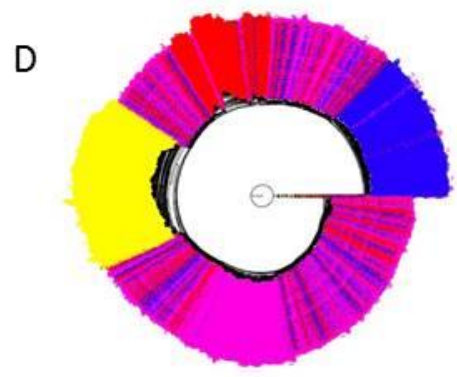

$\overline{0.04}$ 
Supplementary Figure 2: Maximum-likelihood phylogenetic tree constructed with PhyML of RT1 nucleotide sequences issued from the different brain areas. Phylogenetic tree were inferred with nucleotide sequences generated by Sanger sequencing and rooted with HXB2 reference sequence. Branches are colored according to the tissue origin as follow: red: caudate nucleus; blue (C1 and C2: temporal lobe, C3: frontal lobe); green: spinal cord; yellow: brainstem (C2: medulla oblongata and C3: substantia nigra); pink: cerebellum Nodes presenting a branch support $>70 \%$ (bootstrap analysis with 1000 replicates) are indicated by an asterisk

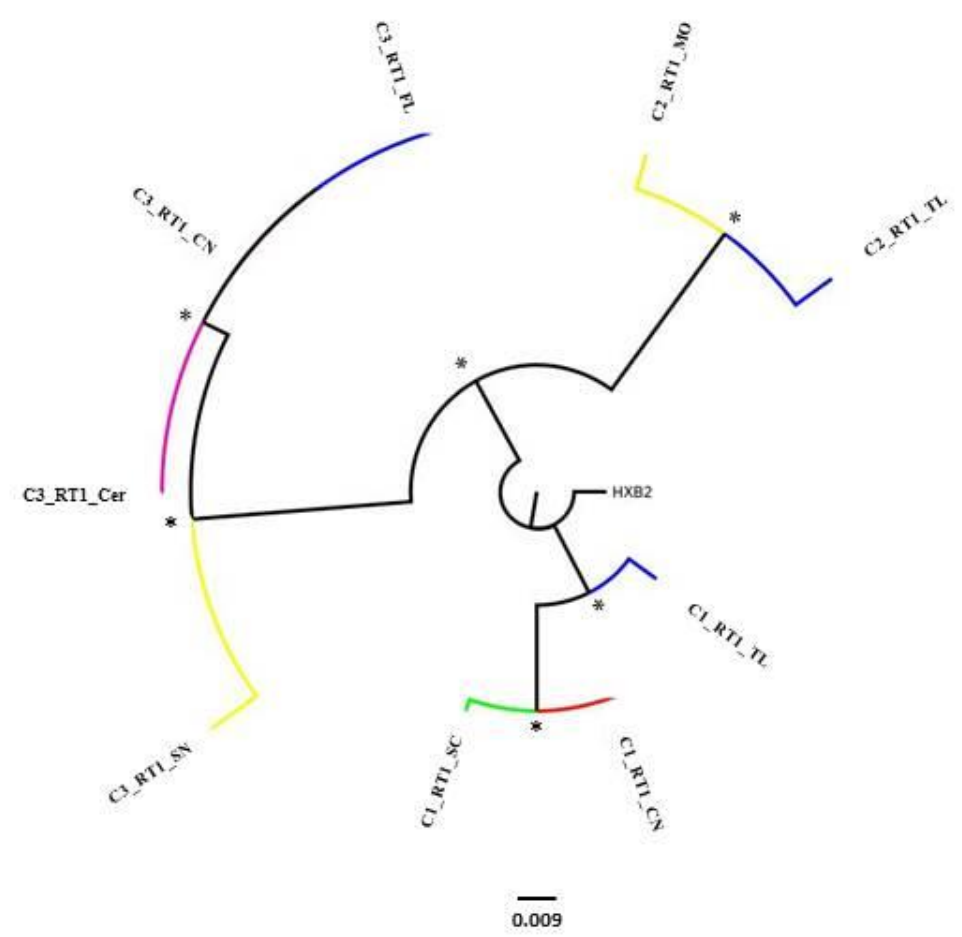


Supplementary Table 1: Participants' characteristics and selected brain areas

\begin{tabular}{|c|c|c|c|c|c|c|c|}
\hline Case & $\begin{array}{c}\text { Age } \\
\text { (years) }\end{array}$ & $\begin{array}{c}\text { HIV } \\
\text { diagnosis }\end{array}$ & $\begin{array}{c}\text { Year of } \\
\text { death }\end{array}$ & Death cause & cART & $\begin{array}{c}\text { Selected } \\
\text { brain areas }\end{array}$ & Anatomopathology \\
\hline 1 & 48 & 1996 & 2006 & $\begin{array}{l}\text { Pulmonary } \\
\text { Embolism }\end{array}$ & Yes & $\begin{array}{l}\text { Temporal lobe } \\
\text { Caudate nucleus } \\
\text { Cerebellum } \\
\text { Spinal cord }\end{array}$ & $\begin{array}{l}\text { Microglial activation and rare } \\
\text { MGC positive for P24 antigen }\end{array}$ \\
\hline 2 & 38 & 2001 & 2010 & Sepsis/ARDS & None & $\begin{array}{c}\text { Temporal lobe } \\
\text { Thalamus } \\
\text { Cerebellum } \\
\text { Medulla oblongata }\end{array}$ & $\begin{array}{l}\text { Rare toxoplasma cysts without } \\
\text { necrosis associated with } \\
\text { numerous microglial nodules }\end{array}$ \\
\hline 3 & 29 & Unknown & 2007 & $\begin{array}{l}\text { Pulmonary } \\
\text { Embolism }\end{array}$ & Yes & $\begin{array}{l}\text { Frontal lobe } \\
\text { Caudate nucleus } \\
\text { Cerebellum } \\
\text { Substantia nigra }\end{array}$ & $\begin{array}{l}\text { Rare toxoplasma cysts without } \\
\text { necrosis associated with } \\
\text { numerous microglial nodules }\end{array}$ \\
\hline
\end{tabular}

ARDS: Acute respiratory distress syndrome. cART: combination antiretroviral therapy. MGC: multinucleated giant cells; HIV: human immunodeficiency virus; ART: antiretroviral therapy; MGC: multinucleated giant cells 
Supplementary Table 2: Experimental conditions for the amplification by nested PCR of RT1, RT2 and V3 region before sequencing on MiSeq Illumina® system.

\begin{tabular}{|c|c|c|c|c|c|c|}
\hline \multicolumn{2}{|c|}{ Amplified fragments } & Primers & Direction & \multicolumn{3}{|c|}{ Sequences $\left(5^{\prime}-3^{\prime}\right)$} \\
\hline \multirow{4}{*}{\multicolumn{2}{|c|}{ RT1 }} & \multirow{2}{*}{ Outer } & Forward & \multicolumn{3}{|c|}{ TAG TCC TAT TGA RAC TGT ACC AGT } \\
\hline & & & Reverse & \multicolumn{3}{|c|}{ ATC CTA CAT ACA ART CAT CCA TG } \\
\hline & & \multirow{2}{*}{ Inner } & Forward & \multirow{2}{*}{\multicolumn{3}{|c|}{$\begin{array}{l}\text { AAG ACT CGG CAG CAT CTC CAA TGG CCA TTG ACA GAA GAA A } \\
\text { GCG ATC GTC ACT GTT CTC CAT GGA ATA TTG CTG GTG ATC C }\end{array}$}} \\
\hline & & & Reverse & & & \\
\hline \multirow{4}{*}{\multicolumn{2}{|c|}{ RT2 }} & \multirow{2}{*}{ Outer } & Forward & \multicolumn{3}{|c|}{ AGT CTT TTG ATG GGT CAT AAT A } \\
\hline & & & Reverse & \multicolumn{3}{|c|}{ GGG ARG TYA ATT AGG AAT ACC } \\
\hline & & \multirow[b]{2}{*}{ Inner } & Forward & \multicolumn{3}{|c|}{ AAG ACT CGG CAG CAT CTC CAG ATG TGG GGA TGC ATA TTT } \\
\hline & & & Reverse & \multicolumn{3}{|c|}{ GCG ATC GTC ACT GTT CTC CAC TGT ATG TCA TTG ACA GTC CAG } \\
\hline \multirow{4}{*}{\multicolumn{2}{|c|}{ V3 }} & \multirow{2}{*}{ Outer } & Forward & \multicolumn{3}{|c|}{ CAG TAC AAT GTA CAC ATG G } \\
\hline & & & Reverse & \multicolumn{3}{|c|}{ ATG GGA GGG GCA TAC ATT G } \\
\hline & & \multirow{2}{*}{ Inner } & Forward & \multirow{2}{*}{\multicolumn{3}{|c|}{$\begin{array}{l}\text { AAG ACT CGG CAG CAT CTC CAT TAC AGT AGA AAA ATT CCC CTC } \\
\text { GCG ATC GTC ACT GTT CTC CAA ATG GCA GTC TAG CAG AAG }\end{array}$}} \\
\hline & & & Reverse & & & \\
\hline \multicolumn{4}{|c|}{ RT1 or RT2 PROTOCOL AMPLIFICATION } & \multicolumn{3}{|c|}{ V3 PROTOCOL AMPLIFICATION } \\
\hline \multicolumn{4}{|c|}{$1^{\text {st }}$ PCR } & \multicolumn{3}{|c|}{$\mathbf{1}^{\text {st }}$ PCR } \\
\hline RT-PCR & $50^{\circ}$ & & $30 \mathrm{~min}$ & RT-PCR & $50^{\circ} \mathrm{C}$ & $30 \mathrm{~min}$ \\
\hline denaturation & 94 & & $7 \mathrm{~min}$ & denaturation & $94^{\circ} \mathrm{C}$ & $7 \mathrm{~min}$ \\
\hline \multirow{3}{*}{35 cycles } & 94 & & $10 \mathrm{sec}$ & \multirow{3}{*}{35 cycles } & $94^{\circ} \mathrm{C}$ & $10 \mathrm{sec}$ \\
\hline & $55^{\circ}$ & & $30 \mathrm{sec}$ & & $53^{\circ} \mathrm{C}$ & $30 \mathrm{sec}$ \\
\hline & 68 & & $1 \mathrm{~min}$ & & $68^{\circ} \mathrm{C}$ & $1 \mathrm{~min}$ \\
\hline 1 cycle & 68 & & $7 \mathrm{~min}$ & 1 cycle & $68^{\circ} \mathrm{C}$ & $7 \mathrm{~min}$ \\
\hline \multicolumn{4}{|c|}{ Nested PCR } & & & \\
\hline denaturation & $98^{\circ}$ & & $1 \mathrm{~min}$ & denaturation & $98^{\circ} \mathrm{C}$ & $1 \min$ \\
\hline 3 cycles & $98^{\circ} \mathrm{C}: 1 \mathrm{C}$ & $; 66-64^{\circ} \mathrm{C}$ & $\mathrm{ec} ; 72^{\circ} \mathrm{C}: 15 \mathrm{sec}$ & 40 cycles & $98^{\circ} \mathrm{C}$ & $10 \mathrm{sec}$ \\
\hline 3 cycles & $98^{\circ} \mathrm{C}: 1 \mathrm{C}$ & ; $64-62{ }^{\circ} \mathrm{C}$ & $\mathrm{ec} ; 72^{\circ} \mathrm{C}: 15 \mathrm{sec}$ & & $60^{\circ} \mathrm{C}$ & $30 \mathrm{sec}$ \\
\hline 3 cycles & $98^{\circ} \mathrm{C}: 1$ & ; 62-60 ${ }^{\circ} \mathrm{C}$ & $\mathrm{ec} ; 72^{\circ} \mathrm{C}: 15 \mathrm{sec}$ & & $72^{\circ} \mathrm{C}$ & $20 \mathrm{sec}$ \\
\hline 30 cycles & $98^{\circ} \mathrm{C}:$ & $\mathrm{cc} ; 60{ }^{\circ} \mathrm{C}:$ & $; 72^{\circ} \mathrm{C}: 15 \mathrm{sec}$ & 1 cycle & $72^{\circ} \mathrm{C}$ & $2 \min$ \\
\hline 1 cycle & $72^{c}$ & & $7 \mathrm{~min}$ & & - & \\
\hline
\end{tabular}

Min : minute ; sec : second ; PCR : polymerase chain reaction ; RT-PCR: reverse transcriptase PCR

Universal Adapters necessary for libraries' preparation are represented in bold. 
Supplementary Table 3: V3 viral diversity and tropism among two different brain area of case 1

\begin{tabular}{|c|c|c|c|c|c|c|c|}
\hline \multirow{2}{*}{ Brain area } & \multicolumn{2}{|c|}{ HIV_V3_CS } & \multicolumn{2}{|c|}{ HIV_V3_CS100 } & \multicolumn{3}{|c|}{ HIV1-tropism } \\
\hline & No of CS & $\begin{array}{c}\text { Consensus } \\
\text { sequences shared }\end{array}$ & No of CS & $\begin{array}{c}\text { Consensus } \\
\text { sequences shared }\end{array}$ & $\begin{array}{c}\text { CCR5 } \\
(\mathrm{FPR}>10 \%)\end{array}$ & $\begin{array}{c}\text { Undetermined } \\
(\mathbf{5 \%}<\mathbf{F P R}<\mathbf{1 0} \%)\end{array}$ & $\begin{array}{c}\text { CXCR4 } \\
(\mathbf{F P R}<5 \%) \\
\end{array}$ \\
\hline Temporal lobe & 2086 & 3 (0.14) with TL & 131 & 0 & $126(96 \%)$ & $5(6 \%)$ & 0 \\
\hline Caudate nucleus & Not amplified & - & Not amplified & - & - & - & - \\
\hline Cerebellum & Not amplified & - & Not amplified & - & - & - & - \\
\hline Spinal cord & 1944 & $3(0.15)$ with SC & 77 & 0 & $72(94 \%)$ & $5(4 \%)$ & 0 \\
\hline
\end{tabular}

immunodeficiency virus; No: number; SC: spinal cord; TL: temporal lobe; -: not applicable

HIV_RTI_CS: all cleaned consensus sequences of RT1 fragment; HIV_RTI_CS100: all cleaned consensus sequences of RT1 fragment after filtering out consensus sequences found less than 100 times 
Supplementary Table 4: Synonymous and non-synonymous polymorphisms not conferring resistance to

Nucleoside and Non-Nucleoside Reverse Transcriptase Inhibitors in different brain areas of cases 1, 2 and 3.

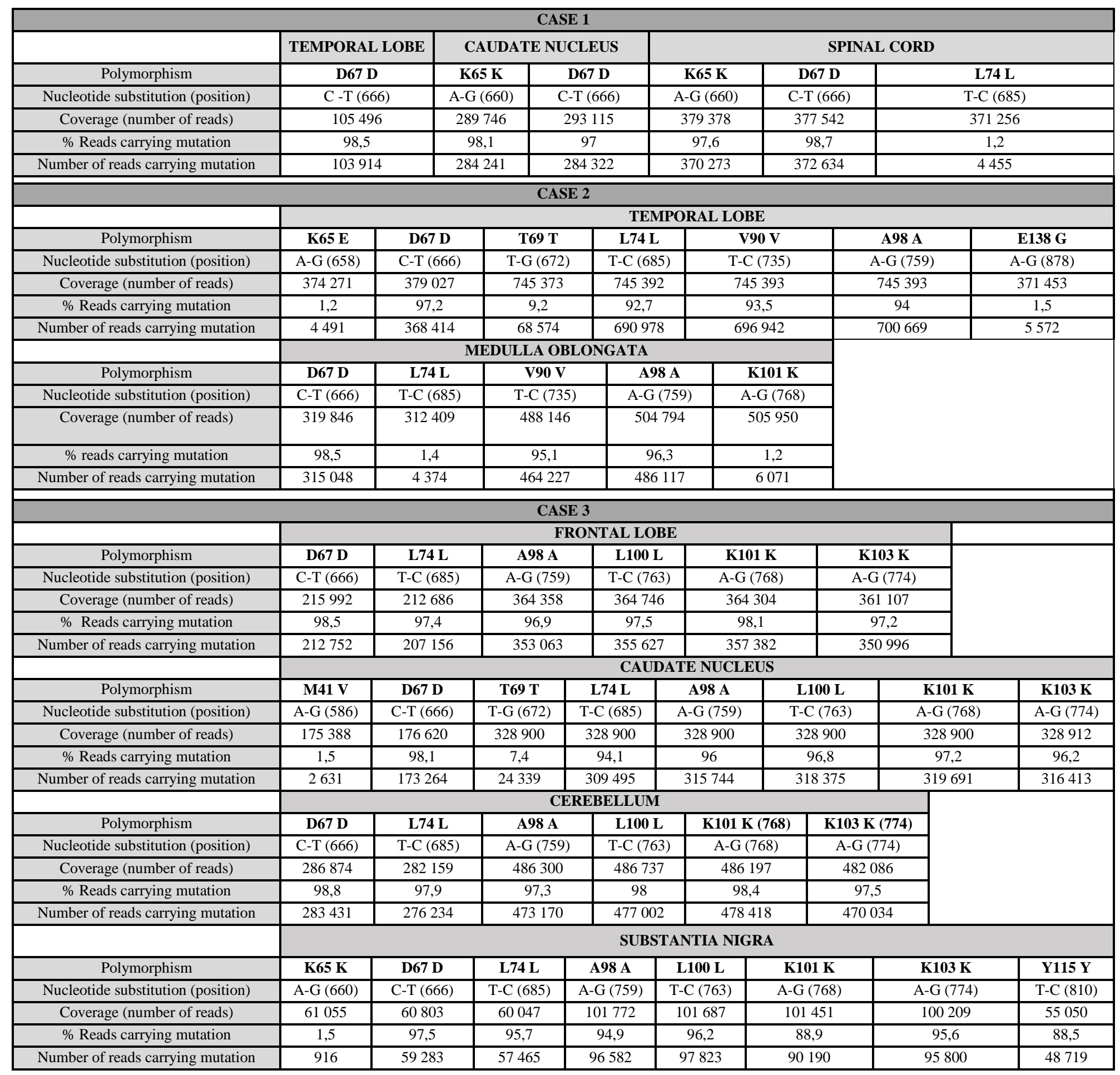

